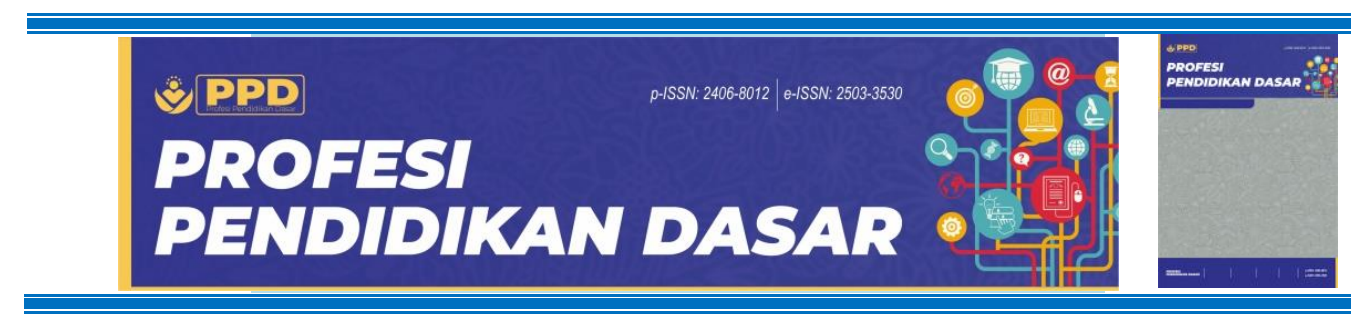

\title{
Analysing Skills of Planning, Conduct, and Assessment In Teachers During Online Mathematics Teaching
}

\author{
Rikana Sulistyaningrum ${ }^{1 *}$, Sutama ${ }^{2}$, Anatri Desstya ${ }^{3}$ \\ 1,2,3 Master of Primary Education, Universitas Muhammadiyah Surakarta, Indonesia \\ *Email: rikana.sulistyaningrum@gmail.com
}

Submitted: 2020-12-30

DOI: $\underline{10.23917 / p p d . v 8 i 1.13108}$

Accepted: 2021-07-10

Published: 2021-07-25

\begin{tabular}{ll}
\hline \multicolumn{1}{c}{ Keywords: } & \multicolumn{1}{c}{ Abstract } \\
\hline online learning; & $\begin{array}{l}\text { The field of education has been confronted with a difficult situation as a result } \\
\text { of the COVID-19 pandemic, which has infected hundreds of countries around } \\
\text { the world. The government has placed multiple policies to combat the effects } \\
\text { of the pandemic, including stopping all face-to-face teaching and replacing } \\
\text { them with online learning. This sudden shift has demanded educators to be } \\
\text { thofessional and be skillfully adaptive in their work processes. This issue is over } \\
\text { three months during the pandemic, specifically from September to November } \\
\text { 2020, whereby six teachers were analyzed. In conclusion, this study found that } \\
\text { some teachers were able to utilize online media, while some still struggled with } \\
\text { it during the COVID-19 pandemic. }\end{array}$ \\
\end{tabular}

\section{INTRODUCTION}

\section{Background}

Early in the year 2020, the whole world began facing the coronavirus (COVID-19) pandemic. This virus was first discovered in Wuhan, China at the end of 2019 (Wiryanto, 2020). Early symptoms of this viral infection include high fever, coughing, runny nose, as well as the loss of taste or smell. If the condition is severe, this virus can cause respiratory system failure and even lead to death. As of current, there is no confirmed study as to the origin of this virus. Many countries have chosen to conduct lockdowns and to implement social distancing in public areas to prevent the further spread of COVID-19. The choice to conduct a lockdown has caused deterioration in multiple governmental sectors as well as public activities, including the education sector (Anugrahana, 2020).

The education sector is faced with a challenging situation as a result of the current COVID-19 pandemic. Since the initial discovery of a suspected COVID-19 patient in Indonesia in February of 2020, all students in Indonesia were forced into a study from a home policy from 16 March 2020 and were not allowed to return to school until the situation stabilizes. Stepping into the tenth month, there is no indication of the end of this pandemic. Case

(C) The Author(s). 2021

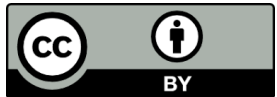

This work is licensed under a Creative Commons Attribution 4.0 International License 
numbers continue to rise in all parts of the country, including in Surakarta and multiple other surrounding cities.

The government demands that educators be more professional during these COVID-19 pandemic times (Sdn \& Bulun, 2020). Teachers were forced to facilitate technology to continue education processes in each of their classes. They had to be innovative in developing their lesson plan, either in the beginning, core, or closing of each of their activities (Kisno et al, 2020). Although classes were being done online, teachers had to maintain their professionalism. As all face-to-face learning, from early childhood education, elementary, and even up to undergraduate studies, were halted, all learning processes were done online (Engelbrecht et al., 2020).

Online learning is the virtual conduct of learning that can include a vast target population. Online learning can be done extensively and can facilitate unlimited, multiple, and variable learning (Yudha \& Herzamzam, 2020). Online learning can be conducted and done either free of charge or not. This situation can be looked at positively and presents as a great opportunity for teachers to explore and learn to facilitate technology in their teaching. In other words, as a result of facing the pandemic, teacher skills of using and facilitating technology-based mediums of teaching can be improved (Wijaya et al., 2020).

The Ministry of Education and Culture has prepared a specifically designed platform to ensure the continuation of education processes even though schools were closed down. This is done by facilitating information and communication technologies. Electronic learning (e-learning) is considered the most appropriate approach for the conduct of education processes throughout the pandemic. In Indonesia, the government recommends Rumah Belajar and SPADA as e-learning platforms. These platforms are free and were developed by the Ministry of Education and Culture as alternative solutions to learning for both students and teachers. SPADA is an e-learning platform developed by the Ministry of Research, Technology, and Higher Education for HEl. The Indonesian Ministry of Education and Culture has also collaborated with several online learning platforms, including MejaKita, ICANDO, Ganeca Digital, Kelas Pintar, Quipper School, Ruang Guru, Sekolahmu, Zenius, Cisco Webex, and Pahamify. All these resources aim to support both students and teachers to successfully conduct studies from home (Mailizar et al., 2020). Schools that have not prepared e-learning resources have difficulty, especially when teachers do not understand how to use online applications (Zaharah et al., 2020).

Throughout the pandemic, learning processes in public elementary school in Surakarta have been conducted using blended learning, whereby a combination of both online and offline learning was done. Online learning has been done using the Whatsapp application, facilitating its available features such as sending photos, videos, andeducational Youtube video links. Each class was further divided up into groups and each group had its own Whatsapp group. Offline learning was done by having small groups of teachers visit students' homes. However this method is still very limited as the goal of this year's curriculum is more focused on maintaining the health and wellbeing of all teachers and students, not high educational achievements.

\section{Problem of Study}

The conduct of remote learning with blended learning has been done in public elementary school in Surakarta. This school is located in the middle of the city. However, this strategic location is not able to guarantee the success of e-learning. There are still many students that have limited access to the internet. As a result, teacher home visits present as one alternative to overcome the limitations of remote learning. However, the conduct of home visits by teachers is still limited by the need to follow health protocols set in place to prevent further infection of COVID-19. 


\section{State of the Art}

Teachers face many challenges when it comes to online teaching. Fauzi \& Kusuma (2020) conducted a study assessing teacher perspectives on online learning in West Java. $73.9 \%$ of the 45 identified respondents stated that online learning was not effective. Challenges associated with online learning include limitations in (1) facilities provided by the school, (2) internet connection, (3) planning, conduct, and assessment of learning processes (Fauzi \& Sastra Kusuma, 2020). In another study by Quadri et al., 2017, the authors identified barriers to the implementation of e-learning. They classified these barriers into four groups, namely students, instructors, infrastructure and technology, as well as institutional management. The study reported that the most significant barrier was instructors and technology, while students presented as the most insignificant barrier. Furthermore, it showed that limited time in developing a proper e-learning system is the most significant barrier to its implementation (Naveed et al., 2017).

The lack of time available to prepare lessons facilitating technology is a major challenge faced by teachers. Hadijah and Shalawatu (2017) explored the obstacles experienced by teachers when conducting e-learning. These include the lack of professional development regarding technology, restrictions of physical resources, technical support, and access to technology, as well as limited competency and self-confidence (Hadijah \& Shalawati, 2017).

\section{Gap Study \& Objective}

Through this study, the authors would like to observe the skills of teachers in facilitating online media for Mathematics during lesson planning, the conduct of learning as well as student assessment or evaluation. This topic was chosen by the author as a result of the need for a basic understanding of the skills of teachers in utilizing online media for teaching Mathematics during a pandemic. Student assessments are regarded as an essential portion of a learning process and should be used by teachers to map each students' achievements during learning. As an important component, student assessments should always be done by teachers to understand the effectiveness of the learning process (Arifin, 2016). The research problem of this study is "How are the skills of teachers in lesson planning, the This study aims to describe the skills of teachers in facilitating online media in Mathematics learning processes during the COVID-19 pandemic.

\section{METHOD}

This study will utilize a qualitative approach. Bogdan and Taylor in Moleong (2012) defined qualitative methodology as a study approach that provides descriptive data in the form of written or spoken words from the observed subjects (Sugiyono, 2020). This study attempts to obtain data that is accurate to the study location and interviewees, thus the author will involve themselves in the environment. The qualitative study method is also known as a naturalistic study as it is conducted in a natural setting (Sugiyono, 2020). This method is also known as ethnographic research, as it was originally majorly used in the field of anthropology.

The interview method was conducted using a semi-structured model, whereby the author prepared seven questions to query the respondents, which was then followed up with other questions to further explore their responses. These questions are related to (1) the teacher's identity, (2) the number of students in their class, (3) the facilities available for online study at the students' homes, (4) the model adopted by the teacher to teach, including for mathematics, (5) their apprehension of information technology (IT), (6) problems that they face during online learning, and (7) their methods of assessing students during online learning. The interview was conducted to identify problems or barriers from respondents in teaching Mathematics online in a more open way. Respondents were class 
teachers and were asked to truthfully discuss problems that they faced throughout teaching in the middle of the COVID-19 pandemic period.

Data was collected through the author's observation by compiling items that contained actions and events experienced by the respondents during online learning. The author prepared several observational indicators correlated to the teacher's role, (1) teachers as educators, instructors, mentors, and theory providers for students, (2) teachers must be able to motivate students, and (3) teachers must be able to develop students' communication skills. The author conducted moderate participation observation, in which there is a balance between their role as both an active part of the group and a passive outsider observing in (Sugiyono, 2020). The author collected data by participant observation in some of the respondent's tasks, although not all of them. The author also collected data through document analysis. These documents are in the form of lesson plans, also known as Rencana Pelaksanaan Pembelajaran (RPP). In addition, the author also analyzed photos of student's assignments sent to the teachers through Whatsapp, as well as those sent to the school by parents.

The author analyzed the collected data utilizing the Cresswell model. Cresswell (2012) mentions that this method of study is able to observe a group of humans that interacts with objects, conditions, or events that are currently happening (Sugiyono, 2020). The data collected are results of author observation, conducted interviews, and documentation from the teachers in an elementary school in Surakarta. Data was observed as a whole and then grouped and coded accordingly for description. The population of interest is teachers in a public elementary school in Surakarta totaling six people, who taught year one to year six. This study will be describing the skills of these teachers in facilitating online media for the purposes of Mathematics learning processes.

\section{RESULT}

The conduct of Mathematics learning processes throughout the COVID-19 pandemic period by teachers in public elementary school in Surakarta is as follows.

\section{Lesson Planning}

Lesson planning was done following guidelines for emergency lesson planning, known as RPP darurat, which only picks out essential topics of study. Generally, all core topics from the 2013 Curriculum for Mathematics were included in the RPP darurat. However, not all of the topics were able to be delivered maximally as there was a limit in time.

At the beginning of the 2020/2021 academic period, the Teacher's Association in Banjarsari subdistrict in Surakarta conducted a workshop to draw up a standardized lesson plan that is adaptive to the COVID-19 pandemic. This was in line with directions from the Ministry of Education and Culture, where all learning processes must be customized and simplified to adapt to virtual learning. Teachers in public elementary school in Surakarta also developed a lesson plan that excluded usual components, including an opening, core objective, and closing.

The lesson plan prepared by the respondents was RPP for Mathematics that was integrated into thematic RPP for younger students (years 1, 2, and 3), and Mathematics specialized RPP for older students (years 4, 5, and 6). A few of the teachers prepared specialized notes on the steps and learning objectives for each Mathematics lesson, although some did not.

For the younger classes, Mathematics lessons were integrated with other subjects according to the thematic RPP, with steps as follows. These are the steps for the Year 2 lesson plan Theme 1, Subtheme 3, Topic 4 Learning Activity. 
Table 1. The steps for the Year 2 lesson plan Theme 1

\begin{tabular}{|c|c|c|}
\hline Offline & Online & Combination \\
\hline- & $\begin{array}{l}\text { 1. The teacher prepares an educational video on } \\
\text { imperative sentences, addition and subtraction, } \\
\text { and techniques of coloring. } \\
\text { 2. The teacher provides assignments through an } \\
\text { online portal/use of google forms or using } \\
\text { Whatsapp application, which includes: } \\
\text { a. Students are asked to identify imperative } \\
\text { sentences that are said by the ceremonial } \\
\text { commander in a Youtube video. } \\
\text { b. Students are asked to work on addition and } \\
\text { subtraction practice questions on page } 121 \text { of } \\
\text { their workbooks. } \\
\text { c. Students are asked to color on a picture. } \\
\text { Parents report on their children's work to their } \\
\text { respective teachers. } \\
\text { Teachers collect completed assignments and } \\
\text { assesses them. }\end{array}$ & - \\
\hline
\end{tabular}

The above online lesson plan for year twos facilitates gadgets already owned by the students. Teachers send materials through educational videos, and assignments are sent through Whatsapp group conversations between teachers and student guardians.

The following is an example of the steps for the Year 5 lesson plan Chapter 3 following basic competency 3.3. It compares two different units of measurement (speed as the division of distance over time, and debit as a division of volume over time).

These are the steps for the year 5 chapter 3 Mathematics subject lesson plan.

Table 2. The steps for the Year 5 lesson plan chapter 3 Mathematics

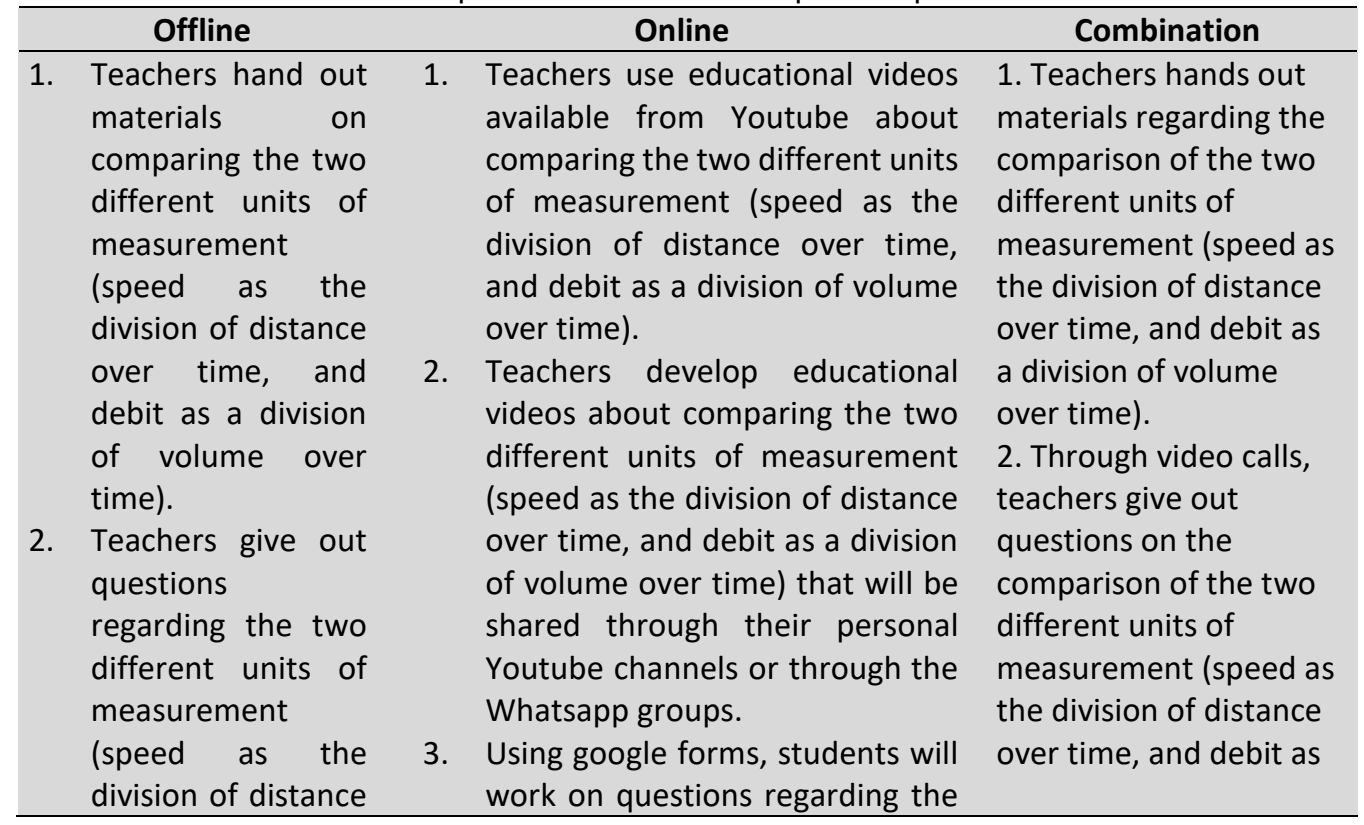


Sulistyaningrum et al. - Analysing Skills of Planning, Conduct, and...

\begin{tabular}{|c|c|c|}
\hline Offline & Online & Combination \\
\hline $\begin{array}{l}\text { over time, and } \\
\text { debit as a division } \\
\text { of volume over } \\
\text { time). } \\
\text { 3. Teachers give out } \\
\text { story-based } \\
\text { problem-solving } \\
\text { tasks regarding the } \\
\text { comparison of two } \\
\text { different units of } \\
\text { measurement } \\
\text { (speed as the } \\
\text { division of distance } \\
\text { over time, and } \\
\text { debit as a division } \\
\text { of volume over } \\
\text { time). }\end{array}$ & $\begin{array}{l}\text { comparison of the two different } \\
\text { units of measurement (speed as } \\
\text { the division of distance over time, } \\
\text { and debit as a division of volume } \\
\text { over time). } \\
\text { 4. Teachers utilize live video calls to } \\
\text { give students assessments on } \\
\text { comparison of the two different } \\
\text { units of measurement (speed as } \\
\text { the division of distance over time, } \\
\text { and debit as a division of volume } \\
\text { over time). }\end{array}$ & $\begin{array}{l}\text { a division of volume } \\
\text { over time) to students. } \\
\text { Using google forms, } \\
\text { students work on } \\
\text { questions regarding the } \\
\text { comparison of two } \\
\text { different units of } \\
\text { measurement (speed as } \\
\text { the division of distance } \\
\text { over time, and debit as } \\
\text { a division of volume } \\
\text { over time). }\end{array}$ \\
\hline
\end{tabular}

In the lesson plan developed for older students, there are different alternatives available for the conduct of learning processes, such as the use of offline learning through home visits, online facilitating gadgets, or using a combination of the two systems,

\section{Conduct of Learning Processes}

The learning process was conducted using a combination of both systems, also known as blended learning. In regard to this, each student has a chance to meet face-to-face with their teacher once a week in groups of five to six students. Teachers conduct home visits according to those groups as well, with a maximum time limit of two hours, as directed by the Surakarta Ministry of Education. The rest of the learning processes are conducted online through the use of Whatsapp. This application was chosen as most students and their guardians are already familiar with the application. Thus, it was hoped that all students would be able to access the study materials given by the teachers in a short amount of time. It would be especially easy if the parents own the phone and have it on their person at all times. This would allow students to access tasks sent through by their teachers while their parents are home, either before or after the parents leave for work. The lesson plan also describes the use of Whatsapp by sending links to readily available educational videos, or videos that have been recorded by the teachers themselves.

The following is an example of an assignment given by a teacher through a class's Whatsapp group. 


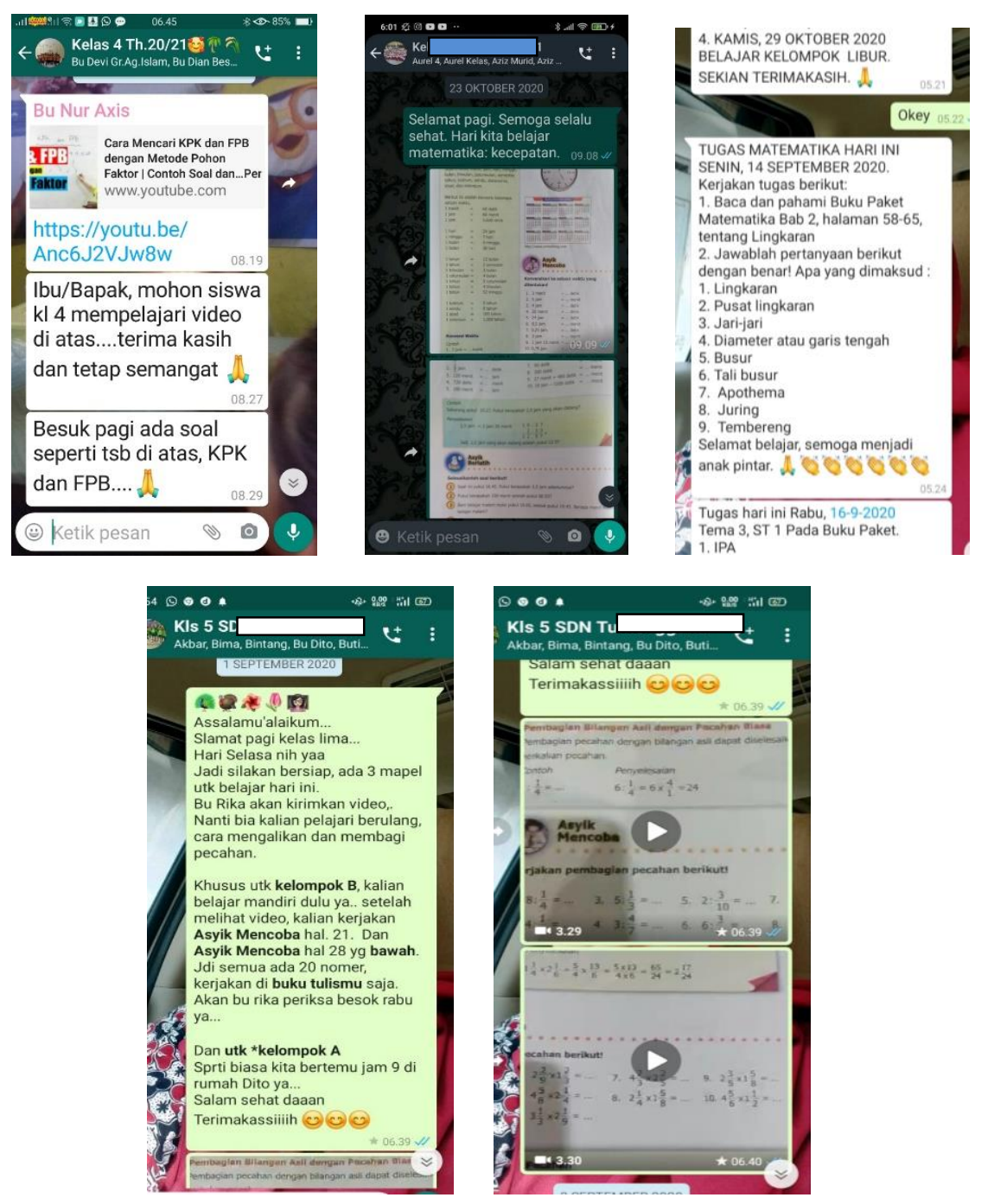

Figure 1. Example of an assignment discussion during online Mathematics class.

Figure 1 shows an example of online conversations through chats conducted by teachers during Mathematics lessons. Teachers only need to deliver study materials that the students would need to study independently, This can be done when the study materials contain sufficient theory for the students to read, understand and memorize. Some teachers facilitate the Whatsapp groups to send videos regarding how to solve an example problem. There are also teachers that facilitate Whatsapp to send through Youtube links about the current Mathematics topic to ease independent learning by the students. One advantage to using this media is that students would be able to watch the videos repeatedly to fully comprehend study materials sent through by their teachers, although this method of learning is less interactive as it is not conducted synchronously (teacher and students are not in the same place at the same time).

Results from the interview done by the author are as follows. Teachers experienced some difficulties in conducting Mathematics classes. Out of all the questions queried by the author, it was found that almost all teachers found difficulty in using the Whatsapp application to deliver study materials. It assisted teachers when the material that was to be delivered had an existing Youtube video. However, if teachers were unable to find an 
appropriate example video, then they had to be innovative and creative by developing their own videos independently.

Through interviews with AD, who is a year 3 teacher, and RI, a year 5 teacher, similar information was collected, in which they both used existing Youtube video links as well as their independently made videos. Both teachers were between 35 to 40 years old and were very familiar with phone applications. On the other hand, in the interview with KM, who was a 53-year-old year 2 teacher, it was found that they did not facilitate existing Youtube videos as much as the previous two teachers. KS delivered mathematics study materials through home visits. KM mentioned that their difficulty in facilitating online media stemmed from their unfamiliarity with phone applications. In addition, they were also hesitant to learn about the use of online media as they were easily sick and felt physically limited. Through interviews with the three other teachers, namely AR (teacher year 1), ST (teaches year 4), and $\mathrm{NH}$ (teaches year 6), it was found that all three facilitated Whatsapp only for delivering assignments. To provide study materials, they chose to conduct it faceto-face through small group home visits.

The following are excerpts of the interviews done with the teachers in public elementary school in Surakarta.

Table 3. The result of interviews with the teachers

Interview with AR, year 1 teacher
Interviewer: "How is the Mathematics learning process in year 1 ? What model did you
choose to conduct the learning process?"
Respondent: "Among the year 1 students, not all are fluent in reading, writing, and
counting, making it difficult for us to teach only through online learning. Especially to
teach mathematics, a special technique is required so the students understand how to
count properly. That is why for the mathematics subject, lessons are done offline
through home visits"
Interview with KM, year 2 teacher
Interviewer: "Why do you choose to conduct face-to-face teaching for mathematics?
Do you find it difficult to use online media?"
Respondent: "I am not too familiar with the applications on my phone. Rather than
having difficulties creating or finding an appropriate video to teach, I am more
comfortable in teaching mathematics face-to-face."
Interview with AD, year 3 teacher
Interviewer: "How is the year 3 students' enthusiasm with online learning for
mathematics? What were the difficulties you faced when teaching the subject?"
Respondent: "The students are less enthusiastic in learning to count using online
methods, especially when they have to work on story-based questions. Parents that
find it difficult to help their children would complain. That is why during home visits, I
would always focus more on mathematics, as most students would require more
direct guidance from their teachers."
Interview with SM, year 4 teacher
you choose for teaching?"
Respondent: "I tried to deliver study materials by taking videos from Youtube, but
turns out that study results from students are still less than expected as the materials
for year 4 mathematics are very complex and they need to be taught step-by-step on
how to solve each of the practice questions."
Inter




\section{Interview with RI, year $\mathbf{5}$ teacher}

Interviewer: "What difficulties did you find during online learning with the year 5 ? How are the results of student assessments of Mathematics in your class?"

Respondent: "Mathematics is supposed to be a fun subject if teachers have a special trick to teach their students. However, because face-to-face lessons with the year 5 are very limited, I helped them by providing examples on how to solve practice questions, either through existing videos from Youtube or my independently developed simple videos. The result of the student assessments is merely on knowledge alone, and I am not able to judge on skill or honesty of the students in answering the questions, as a lot of the assignments students may get help from their older siblings or from their parents. However, I can still give assessments on the students' attitude during home visits."

\section{Interview with $\mathbf{N H}$, year $\mathbf{6}$ teacher}

Interviewer: "How do you conduct student assessments for mathematics through online learning?"

Respondent: "The marks that I give for Mathematics lessons are merely to judge their cognitive, knowledge, and skills. This is because face-to-face interaction is so limited. However, from the way or process of solving the mathematics problems, I can see the discipline of my students. The results are not as satisfying, but it is understandable as mathematics require accuracy and a high level of understanding."

Generally, some of the younger teachers are still able to create their own educational videos using applications on their personal phones. However, for a teacher that is older, they are generally more reluctant to learn how to facilitate the applications on their phones. This often causes difficulty during the Mathematics learning process. To overcome this difficulty, teachers of SD N conducted face-to-face learning for Mathematics using home visits. In addition, some teachers also facilitated existing videos on Youtube by sharing their links.

\section{Student Assessment}

During student assessment, teachers send through assignments according to the materials that have been previously discussed. The tasks are sent through in the form of photos or documents that need to be accessed by the guardians' respective phones. A problem arises when the guardian's phones do not have the same application as the teachers', and thus are unable to access the sent documents. Results of the Mathematics learning process are sometimes not as satisfying as hoped. According to the syllabus, each theme of Mathematics study is to be done in a minimum of 10 learning hours (Kurikulum, 2017). Meanwhile, it is very difficult to conduct face-to-face studies during the pandemic. This leads to difficulties in knowing how well students are able to solve the mathematics problems, as it is a subject that requires assessment of a whole process, not just the results of the work (Muthy, 2018). Students are forced to practice independently as guidance from teachers is very limited. This causes students to often not work on their assignments as maximally as they can, solving questions with less appropriate processes or even with steps that are incorrect. This causes their Mathematics knowledge to be less than optimal.

This is the core source of the problem, whereby students require repeated explanations from their teachers to fully understand learning materials in Mathematics. As a result, if learning is only done online without face-to-face interaction with the teacher, only a small portion of students would be able to obtain a good understanding of Mathematics.

\section{DISCUSSION}


Results of this study in SD N in Surakarta found that the conduct of Mathematics learning processes during the pandemic faces many challenges. Lesson planning that was done is known as emergency RPP and adapts to the conditions and situation of the current COVID19 pandemic, in which only essential study materials are delivered. In the conduct of the Mathematics lesson, the minimal face-to-face interaction led to less than maximal student achievement. This was because students required more guidance from teachers to learn and understand the many materials in Mathematics (Hasbullah, 2017).

Mathematics knowledge is very beneficial for all individuals in day-to-day life and is used by everyone. Life skills can be obtained through an understanding of Mathematics since young. It is always associated with all daily activities, ranging from simple activities such as cooking rice and measuring the right amount of water, to the measuring of cement, water, and sand ratios in building houses.

The lesson contents in the 2013 Curriculum with the concept of independent study that was introduced by the Minister of Education and Culture, Nadiem Makarim, provide schools and teachers to decide on their own educational targets. Especially in the midst of this pandemic, the emergency curriculum allows schools the freedom to choose which are the essential topics. However, in regards to teaching Mathematics, teachers of SD N find that online learning is not effective.

The mastery of mathematics concepts by students especially in younger classes can be done through games, with three stages as follows; a) Understanding of concepts using things and concrete events, b) The process of concrete thinking during the transition period by introducing the shapes of its symbols, c) The visualization of symbols, such as integers as numbers and colors to describe the size of a room (Amalina, 2020). An interesting and stimulating learning process of Mathematics would generally facilitate learning tools such as toys, including artificial media Bundaran Pecahan, Kaliberkuon, Taktik Butarna, and so on. The study entitled Repeated Subtraction for Year 2 students showed that the game Bubble Match helped students to understand division as a concept of repeated subtraction (Anugrahini \& Windrawanto, 2017).

This mastery of concepts is difficult to be done without direct interaction between students and teachers. This is why it would be difficult for teachers to assess their students' understanding of a concept through online learning. Teachers are faced with a situation that demands them to be more creative in providing knowledge to their students. Teachers need to learn more about online media that can be facilitated in the learning process of Mathematics. The study by Mailizar et al., (2020) states that in those with more experience, it is important to develop necessary skills so that lessons are more effective (Mailizat et al., 2020). This is in line with what is happening in SD N Surakarta, whereby reluctance to expand skills is more apparent in more senior teachers.

In the student assessment of Mathematics, teachers in SD N merely conducted tests to fill out their grading forms. Indicators of competence are supposed to include several aspects, including cognitive, affective, and psychomotor skills. These are less able to be observed. Assessments of the study process are often not conducted. This happens because teachers are not directly involved in ensuring the skills of students in solving Mathematics problems. The biggest negative impact to come from this is that students will not be fully equipped with the necessary skills. Many tests that were originally supposed to be done by the students are suddenly canceled or postponed. The curriculum achievements that were targeted are not fulfilled, and for those students who have mastered many concepts or skills, they are not able to obtain their proper grades.

The readiness of teachers in facilitating online learning media for Mathematics is highly necessary. Teachers must try to improve and develop their technology-based skills and are demanded to be able to conduct effective learning processes even when they cannot meet 
face-to-face with their students (Syah, 2020). In the 5th National Seminar for Mathematics and Mathematics Studies (SENATIK) 2020, Murtafiah et al., (2020) provided the results of their study on the delivery of Mathematics lessons by teachers throughout the COVID-19 pandemic. Types of material delivery methods include: 1) The technique of material delivery that is dominantly done by teachers include uploading materials, uploading videos, and asking students to open books or workbooks; 2) Platforms that has been effectively used to deliver materials include WhatsApp, Google Classroom, Zoom, and YouTube; 3) Teachers often directs students to learn independently by facilitating the applications WhatsApp, Google Classroom, and Youtube that can be accessed by students at any time in their own homes, 4) The delivery of materials that are beneficial, according to teachers are uploading videos with materials, a multi-strategy approach (using a combination of multiple platforms), and asking students to open books or workbooks (Murtafiah et al., 2020).

To overcome problems in learning processes that are correlated to the limited teacher skills, the author suggests that: 1 ) Steps to the conduct of Mathematics online learning should be prepared as effectively as possible. Teachers cannot burden students with independent tasks that are supposed to be obtained in school through conventional methods, which is through explanations from teachers, or other methods that are aimed to increase the active participation of students in school. The teacher can be present temporally through the conduct of home visits in small groups; 2) Teachers have to make an effort to develop their skills, especially in the use of online media for Mathematics learning processes, 3) Schools as an institution that organizes the delivery of education is responsible for facilitating the different changes that occur as a result of the shift from a school-centered study to a home-centered study.

\section{CONCLUSION}

The conduct of remote learning processes or online learning for Mathematics in SD N in Surakarta was done with several limitations. In addition to some students being underfacilitated, the skills of teachers in utilizing online media is also a problem in itself. During lesson planning, teachers prepare lesson plans in a very simplistic manner by only choosing essential materials only. The conduct of Mathematics learning processes in SD N Surakarta was done with a blended learning system, in which for older classes, offline systems were still done using home visits. This was because students still required direct interaction with teachers in the process of learning mathematical concepts.

Student assessments during the COVID-19 pandemic were done based on the readiness and skills of teachers in facilitating technology. Assessments for cognitive, affective, and psychomotor aspects were not effectively done. Assessments were done only as an accountability report to the schools, students, and parents. A positive impact of online Mathematics learning is that teachers are pushed to be more creative and innovative. Although some parties are still reluctant to improve their skill, generally teachers will still be motivated to try their best in delivering study materials to their students in limited situations and with a lack of face-to-face interaction.

\section{REFERENCES}

Amalina, A. (2020). Pembelajaran Matematika Anak Usia Dini di Masa Pandemi COVID-19 Tahun 2020. Jurnal Obsesi : Jurnal Pendidikan Anak Usia Dini, 5(1), 538. https://doi.org/10.31004/obsesi.v5i1.592

Anugrahana, A. (2020). Hambatan, Solusi dan Harapan: Pembelajaran Daring Selama Masa Pandemi Covid-19 Oleh Guru Sekolah Dasar. Scholaria: Jurnal Pendidikan Dan Kebudayaan, 10(3), 282-289. https://doi.org/10.24246/j.js.2020.v10.i3.p282-289

Anugrahini, M., \& Windrawanto. (2017). PENGEMBANGAN GAME BUBBLE MATCH SEBAGAI MEDIA PEMBELAJARAN PEMBAGIAN DALAM BENTUK PENGURANGAN 
BERULANG UNTUK SISWA KELAS 2 SD. Journal on Mathematics Education, 4(1),7583.

Arifin, Z. (2016). EVALUASI PEMBELAJARAN : Prinsip, Teknik, dan Prosedur (P. Latifah (ed.); 7th ed.). PT Remaja Rosdakarya.

Hadijah, S., \& Shalawati. (2017). Investigating Teachers' Barriers To Ict (Information Communication Technology) Integration In Teaching English At Senior High Schools In Pekanbaru. Proceeding of the Fifth International Seminar on English Language Teaching (ISELT-5), 5(1), 302-310.

Hasbullah. (2017). IEJME_1984_article_5a2e491db1167. 12(10), 859-872.

Kisno, K., Turmudi, T., \& Fatmawati, N. (2020). Pelaksanaan Penilaian Matematika Di Sekolah Dasar Selama Masa Pandemi. Martabat: Jurnal Perempuan Dan Anak, 4(1), 97-110. https://doi.org/10.21274/martabat.2020.4.1.97-110

Kurikulum, T. P. (2017). SILABUS MATEMATIKA SEKOLAH DASAR KURIKULUM 2013 (2017th ed.). Dikdasmen.

Mailizar, Almanthari, A., Maulina, S., \& Bruce, S. (2020). Secondary school mathematics teachers' views on e-learning implementation barriers during the COVID-19 pandemic: The case of Indonesia. Eurasia Journal of Mathematics, Science and Technology Education, 16(7). https://doi.org/10.29333/EJMSTE/8240

Murtafiah, W., Suwarno, S., \& Lestari, N. D. S. (2020). Exploring the types of a material presentation by teachers in mathematics learning during the COVID-19 pandemic. Journal of Physics: Conference Series, 1663(1). https://doi.org/10.1088/17426596/1663/1/012043

Muthy, A. N. \& P. H. (2018). Jurnal Math Educator Nusantara ( JMEN ). Jurnal Math Educator Nusantara, 4(2), 157-167.

Naveed, Q. N., Muhammed, A., Sanober, S., Qureshi, M. R. N., \& Shah, A. (2017). Barriers effecting successful implementation of E-learning in Saudi Arabian Universities. International Journal of Emerging Technologies in Learning, 12(6), 94-107. https://doi.org/10.3991/ijet.v12i06.7003

Sdn, A., \& Buluh, T. (2020). Efforts To Improve Teachers' Competence in Preparing Lesson Plan During the Covid-19 Pandemic Through in House Training. Pendidikan Dan Pengajaran, 4(November), 1259-1266. http://dx.doi.org/10.33578/pjr.v4i6.8191

Sugiyono. (2020). Metode Penelitian Kuantitatif, Kualitatif, dan R\&D (Sutopo (ed.); 2nd ed.). Alfabeta.

Syah, R. H. (2020). Dampak Covid-19 pada Pendidikan di Indonesia: Sekolah, Keterampilan, dan Proses Pembelajaran. SALAM: Jurnal Sosial Dan Budaya Syar-I, 7(5). https://doi.org/10.15408/sjsbs.v7i5.15314

Wijaya, T. T., Ying, Z., Purnama, A., \& Hermita, N. (2020). Indonesian students' learning attitude towards online learning during the coronavirus pandemic. Psychology, Evaluation, and Technology in Educational Research, 3(1), 17-25. https://doi.org/10.33292/petier.v3i1.56

Wiryanto. (2020). Proses Pembelajaran Matematika di Sekolah Dasar di Tengah Pandemi COVID-19. Jurnal Review Pendidikan Dasar: Jurnal Kajian Pendidikan Dan Hasil Penelitian, 6(2), 125-132.

Yudha, C. B., \& Herzamzam, D. A. (2020). Learning Mathematics in Pandemic COVID-19. JPD: Jurnal Pendidikan Dasar, 1(1), 1-15.

Zaharah, Kirilova, G. I., \& Windarti, A. (2020). Dampak wabah virus corona terhadap kegiatan belajar mengajar di Indonesia. Salam: Jurnal Sosial Dan Budaya Syar'i, 7(3), 269-282. http://journal.uinjkt.ac.id/index.php/salam/article/view/15104/0 